\title{
A new species of Solepyris Azevedo (Hymenoptera, Bethylidae) from Brazil, with amended diagnosis of the genus
}

\author{
Celso O. Azevedo ${ }^{1}$ \\ 'Departamento de Biologia, Universidade Federal do Espírito Santo, Av. Marechal Campos 1468, 29040-090 Vitória-ES, Brazil. \\ bethylidae@gmail.com

\begin{abstract}
A new species of Solepyris Azevedo (Hymenoptera, Bethylidae) from Brazil, with amended diagnosis of the genus. Solepyris Azevedo is a rarely collected Neotropical genus. It is differentiated from other Sclerodermini genera by having the fore wing venation with a single large closed cell and currently is monotypic containing $S$. unicus Azevedo. A second species, Solepyris montuosus, sp. nov., from Brazil is described and illustrated. This new species is diagnosed by having radial vein of the fore wing long. An amended diagnosis of Solepyris unicus Azevedo is included. A key for the two species of Solepyris is provided.
\end{abstract}

KEYWORDS. Epyrinae; Neotropical; Sclerodermini; taxonomy.

\begin{abstract}
RESUMO. Uma nova espécie de Solepyris Azevedo (Hymenoptera, Bethylidae) do Brasil, com diagnose emendada do gênero. Solepyris Azevedo é um gênero neotropical raramente coletado. O gênero é reconhecido dentre os gêneros de Sclerodermini por possuir a nervação das asas anteriores com apenas uma célula fechada grande. É descrita e ilustrada uma segunda espécie, Solepyris montuosus, sp. nov., do Brasil. Esta espécie é caracterizada por possuir a nervura radial da asa anterior longa. É incluída uma diagnose emendada de Solepyris unicus Azevedo. Foi fornecida uma chave para as duas espécies de Solepyris.
\end{abstract}

PALAVRAS-CHAVE. Epyrinae; Neotropical; Sclerodermini; taxonomia.

Solepyris was described by Azevedo (2006) to accommodate a very unusual species of Sclerodermini from Brazil (state of Minas Gerais) and Ecuador with the body flattened, the prosternum with the anterior margin convex and the fore wing venation with a single large closed cell.

Solepyris is thought to be most closely related to Megaprosternum Azevedo (Lanes \& Azevedo 2008), because both genera have a pronotal disc with the posterolateral corners overlapped by the mesoscutum, which extends laterally beyond the anterior margin of the mesoscutum and also a large prosternum, which resembles species of Scolebythidae (Azevedo 2006).

This genus is rarely collected and up to now is based on only three specimens deposited in museums. Nevertheless, additional specimen of Solepyris has been collected in a small area of mountainous Atlantic rain forest. Nothing is known regarding the hosts of Solepyris.

The goal of this study is to summarize the available information about this genus and propose a new species from Brazil (Espírito Santo).

\section{MATERIALAND METHODS}

Specimens. Efforts were made to study all available specimens of the genus. Additionally, species of other cladistically related genera of Sclerodermini were investigated in order to find other possible Solepyris species. Many collections were visited and requested but no additional material was found.
Collections. The material was kindly provided by the following institutions: CNCI - Canadian National Collections of Insects, Canada (J. Huber); UFES - Universidade Federal do Espírito Santo, Brazil (author); and UFMG - Universidade Federal de Minas Gerais, Brazil (F. Silveira).

Taxonomic Treatment. Measurements and indices used in this study are as follows: body length measured from the apex of clypeus to the posterior margin of the last metasomal segment, excluding male genitalia or female sting; LH, length of head, measured in frontal view, from vertex crest to median apical margin of clypeus; WH, width of head, measured in frontal view, its maximum width including eyes; WF, width of frons, measured in frontal view, its minimum width, usually about bottom of eyes; HE, height of eye, measured in lateral view, across its maximum height (length); OOL, ocello-ocular line, measured in latero-dorsal view, the shortest distance from eye top to posterior ocellus; WOT, width of ocellar triangle, measured in frontal view, maximum width, including ocelli; $\mathrm{DAO}$, diameter of anterior ocellus, measured in frontal view; distance of ocellar triangle to vertex: measured in dorsoposterior view, distance from posterior ocellus to vertex crest; VOL, vertex-ocular line, measured in dorsal view, distance from eye top to vertex crest.

The nomenclature of integument sculpture follows Harris (1979), and general terms follow Evans (1964) and Azevedo (1999). 


\section{Solepyris Azevedo, 2006}

Diagnosis of females. Body slightly flattened. Full winged; tegula present. Clypeus short. Antenna 13-segmented Mandible not elongate. Eye situated forward on head. Palpal formula 6:3. Head slightly wider than maximum thorax width. Notaulus absent. Parapsidal furrow conspicuous. Pronotal disc slightly depressed anteriorly, lateral face strongly concave. Scutellum separated from mesoscutum by suture. Fore wing only with subcostal, basal, transverse median and anal veins; median and submedian cells fused by absence of median vein, subcostal vein much dilated distally, prostigma small and stigma absent (Figs. 5, 10). Femora not very dilated. Tibial spur formula 1:1:1.

Males. Unknown.

Key for females

1. Temple not diverging anterad in dorsal view (Fig. 1); scutellar groove inconspicuous (Fig. 1); propodeal disc with posterior transverse carina (Fig. 1); fore wing without radial vein (Fig. 4) ................................. S. unicus Azevedo

Temple diverging anterad in dorsal view (Fig. 5); scutellar groove conspicuous (Fig. 5); propodeal disc without posterior transverse carina (Fig. 5); fore wing with elongate radial vein (Fig. 8) .......... S. montuosus, sp. nov.

\section{Solepyris unicus Azevedo, 2006}

(Figs. 1-4)

Diagnosis. Female. Body length $3.9 \mathrm{~mm}$. Dark castaneous. Head (Fig. 1). Mandible narrower apically with three apical teeth (Fig. 2). Clypeus extremely short, extending backward into frons, apical margin convex and situated behind level of anterior margin of torullus, without median carina. Antennal torulli distant each other $1.8 \mathrm{x}$ their own diameters. Eye with sparse setae. Frons coriaceous with few sparse small punctures. LH 1.12-1.15x WH, WF 0.57-0.60x WH, WF 1.101.32x HE, ocellar triangle compact, OOL 2.2-2.3x WOT, frontal angle of ocellar triangle acute, posterior ocelli distant from vertex crest 2.3-3.3x DAO. Vertex almost straight with rounded corner. Temple subparallel. VOL 1.0-1.32x HE. Occipital carina present, but weak. Mesosoma (Fig. 2). Notaulus absent. Parapsidal furrow complete but very weak. Scutellum slightly shorter than mesoscutum, scutellar groove nearly straight, not crossing all anterior width of scutellum, shallow, ends little dilated and angled backward. Propodeal disc about as long as median width, transverse anterior carina defined but narrow, median carina not defined, instead there is areolate basal triangle with median irregular striae, otherwise disc weakly areolate, posterior transverse carina present; anterior corner with oblique foveolate groove; declivity polished, without median carina. Prosternum triangular with anterior margin convex, lateral margins hardly concave, $1.26 \mathrm{x}$ as long as wide; width about $0.8 \mathrm{x}$ length of propleuron, posterior vertex narrow but rounded and surpassing anterior margin of pleurosternum (Fig. 3). Mesopleuron with small central pit. Fore wing without radial vein (Fig. 4). Legs not spinose. Hind legs with coxae very close each other.

Material examined. Holotype, female: Ecuador, Pich[incha], Rio Palengue, II.1976, Mal[aise] tr[ap], J. Bellwood col. (CNCI). Paratypes [in bad conditions, without head], 2 females: Brazil, M[inas] G[erais], Belo Horizonte, UFMG Est[tação] Ecológica 25-26.XI.1996, arm[adilha] Malaise; J. C. R. Fontenelle col. (UFMG, UFES).

\section{Solepyris montuosus sp. nov.}

(Figs. 5-8)

Description. Female. Body length $3.4 \mathrm{~mm}$, LFW $2.1 \mathrm{~mm}$. Color: body dark castaneous nearly black; clypeus nearly black, mandible and antennae dark castaneous, coxae, trochanters, femora and mid and hind tibiae dark castaneous, fore tibia and tarsi castaneous, wings hyaline with broad subhyaline spot around radial vein, veins dark castaneous.

Head (Fig. 5). Mandible narrowing apicad, with three apical teeth (Fig. 6). Clypeus weakly coriaceous, extremely short, extending backward into frons, apical margin convex in dorsal view and medially elevated in frontal view, and situated beyond level of anterior margin of torulli, median carina absent. First four antennal segments in ratio of about 14:5:4:4, flagellomere hardly longer than wide, cross section of scape elliptical; pubescence suberect, about $0.5 \mathrm{x}$ as long as diameter of flagellomeres, few setae longer. Antennal torulli distant each other $1.5 \mathrm{x}$ their own diameters. Antennal scrobe not carinate. Eye slightly ovoid with sparse setae, situated predominantly on dorsal half in lateral view. Frons coriaceous with few sparse small punctures. Malar space narrow, median width $0.25 \mathrm{x}$ basal width of mandible. WH 1.14x maximum mesosomal width. $\mathrm{LH}$ 1.06x WH, WF 0.56x WH, WF 1.19x HE, ocellar triangle compact, OOL 2.0x WOT, frontal angle of ocellar triangle acute, posterior ocelli distant from vertex crest 3.0-5.0x DAO. Vertex convex with corner broadly rounded. Temple diverging anterad. VOL 0.98x HE. Occipital carina absent.

Mesosoma (Fig. 5). Thorax coriaceous as frons. Pronotal disc with maximum width $2.5 \mathrm{x}$ maximum length, posterior margin evenly slightly concave in dorsal view, not paralleled by series of small foveae, length ratio of pronotal disc/mesoscutum/ scutellum in about 1.2:1:1. Notaulus absent. Parapsidal furrow straight, not reaching posterior margin of mesoscutum. Scutellum wide, posterior margin overlapping propodeal disc. Scutellar groove straight, wide, deep, crossing nearly all anterior width of scutellum, ends little dilated. Propodeal disc $1.0 \mathrm{x}$ as long as median width, areolate basally, and progressively weakened posterad, transverse anterior carina defined but narrow, median and transverse posterior carinae absent, area lateral to carina with irregular texture, lateral carina displaced downward and incomplete anteriorly, spiracles elliptical, slightly displaced to lateral of propodeum, anterior corner with oblique foveolate groove; propodeal declivity mostly polished, lateral area with long pale setae, median carina absent; lateral of propodeum less areolate than disc. Propleuron wide. Prosternum triangular with anterior margin convex, lateral margin concave, $1.2 \mathrm{x}$ as long as wide; prosternum width $0.75 \mathrm{x}$ 


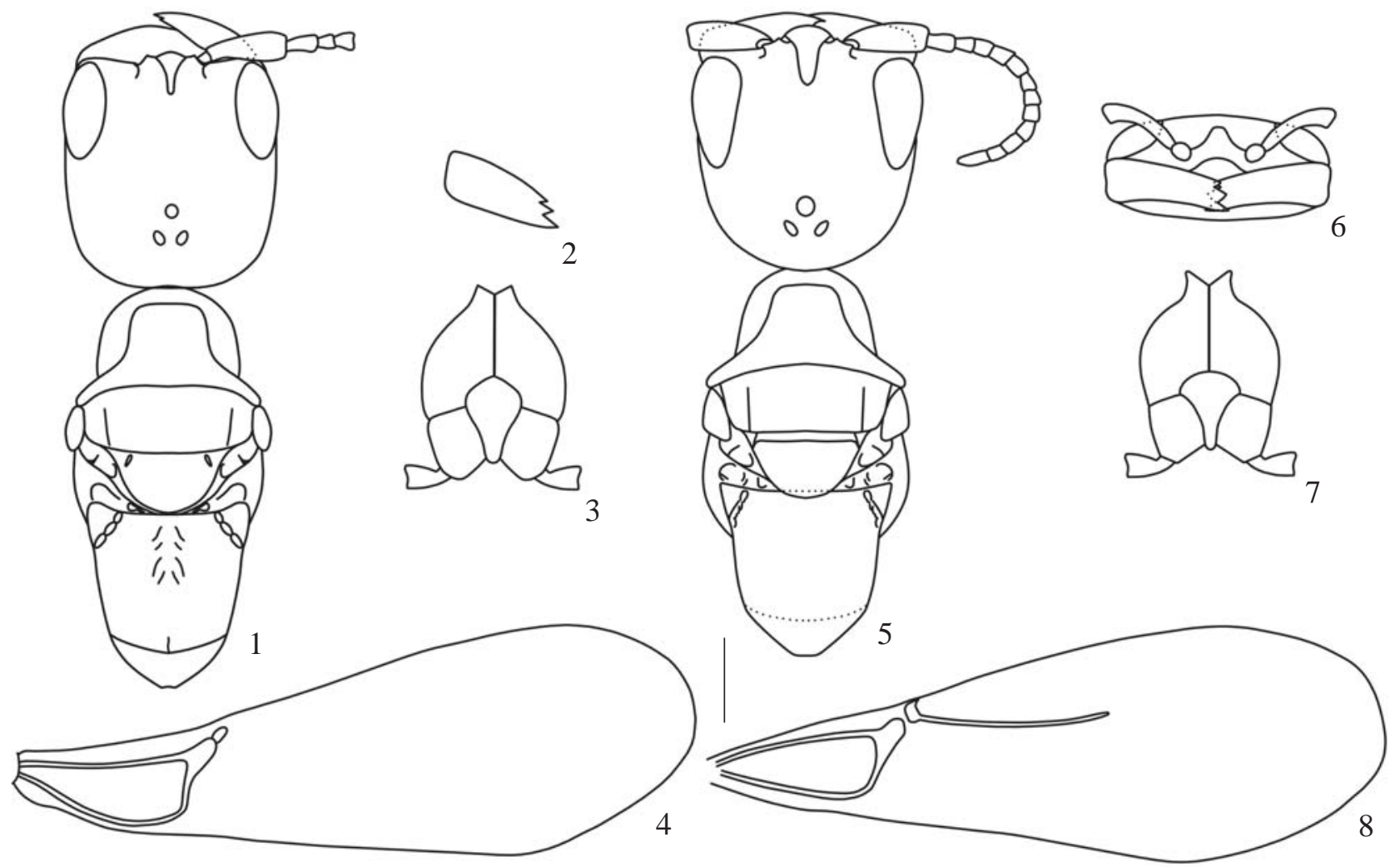

Figs. 1-4. Solepyris unicus: 1, head and mesosoma, dorsal view; 2, mandible, frontal view; 3, anterior mesosoma, ventral; 4, fore wing, dorsal view; 5-8. S. montuosus sp. nov.: 5, head and mesosoma, dorsal view; 6, head, frontal view; 7, anterior mesosoma, ventral view; 8, fore wing, dorsal view $($ scale bar $=250 \mu \mathrm{m})$.

propleuron length, posterior vertex narrow but rounded and surpassing anterior margin of pleurosternum (Fig. 7). Mesopleuron weakly coriaceous, little bulging in dorsal view, central pit small rounded, subtegular fovea undefined, prepectal carina absent. Mesosternum without median groove, with median fovea on posterior half, posterior area depressed. Metasternum wider than long, posterior margin somewhat carinate. Fore wing with radial vein, $0.27 \mathrm{x}$ as long as fore wing (Fig. 8). Hind wing with two basal and four median hamuli, latter evenly distant one to another. Fore femur $2.5 \mathrm{x}$ as long as wide. Hind legs with coxae very closed each other. Fore tibia shorter than fore femora, mid tibia as long as mid femur, hind tibia longer than hind femur, basitarsus of all legs much longer than second tarsomere. Claws simple and evenly arched.

Metasoma. Nearly polished; tergites and sternites with few long setae mostly placed laterally and posterior on each segment, except last sternite more densely setose; transverse section elliptical. Posterior margin of sternites evenly curved, but not bi-emarginate. Transverse section elliptical. Length of metasoma about $1.3 \mathrm{x}$ length of mesosoma.

Material examined. Holotype, female: Brazil: Espírito Santo, Alfredo Chaves Picadão, mata \{=forest $\}, 20^{\circ} 27^{\prime} 53^{\prime \prime} \mathrm{S} 40^{\circ} 42^{\prime} 35^{\prime \prime} \mathrm{W}, 8$ 15.X.2007, arm[adilha] \{=trap\} Malaise, C.O. Azevedo \& eq[uipe] \{=team\} col. (UFES \#09018). Paratype, female: Brazil: Espírito Santo, Domingos Martins, [ 20 $20^{\circ} \mathrm{S} \quad 40^{\circ} 40^{\prime} \mathrm{W}$ ], 5-12.VII.2003, arm[adilha] $\{=$ trap $\}$ Malaise, R. Kawada col. (UFES \#18525).
Variations. Body length $4.4 \mathrm{~mm}$; LFW $2.6 \mathrm{~mm}$; slightly darker; fore wing with subhyaline spot around basal vein; Antennal torulli distant each other $1.7 \mathrm{x}$ their own diameters; malar space wider, median width $0.45 \mathrm{x}$ basal width of mandible; WH 1.10x maximum mesosomal width; LH 1.05x WH; WF 0.59x WH; WF 1.27x HE; OOL 1.89x WOT; posterior ocelli distant from vertex crest 5.0x DAO; VOL 1.0x HE; pronotal disc with maximum width $2.48 \mathrm{x}$ maximum length; length ratio of pronotal disc/mesoscutum/scutellum in about 1.3:1:1; propodeal disc $0.93 x$ as long as median width, strongly areolate basally, area lateral to carina more coarsely textured, anterior corner with conspicuous oblique foveolate groove; prosternum $1.25 \mathrm{x}$ as long as wide; radial vein of fore wing $0.26 \mathrm{x}$ as long as fore wing; fore wing with a very small stub of median vein raising from basal vein; hind wing with four or five median hamuli; fore femur $2.3 \mathrm{x}$ as long as wide; length of metasoma $1.5 \mathrm{x}$ length of mesosoma.

Etymogeny. The epithet specific refers to the mountainous area where the type was collected.

\section{DISCUSSION}

Solepyris montuosus, sp. nov., represents the second species of the genus. It is known only from a single female collected in an area of mountainous Atlantic rain forest. This area is located about $32 \mathrm{~km}$ in straight line distances from the 
Atlantic ocean, and about $350 \mathrm{~km}$ straight line distance from Belo Horizonte (Brazil, Minas Gerais), which is the closest locality of Solepyris unicus. This broadens the distribution of the genus, and suggests that this genus has broad distribution ranging throughout several sites in South America.

Solepyris montuosus, sp. nov., differs from S. unicus in many features. The main characters are pointed out in the key. Besides these differences $S$. montuosus, sp. nov., anterior area of pronotal disc is little depressed, the series of foveae in the anterior area of propodeal disc is composed of fused foveae, whereas S. unicus has anterior area of pronotal disc well depressed, and the series of foveae in the anterior area of propodeal disc is composed of isolated foveae, but closed one to another.

Although Azevedo (2006) stated that Solepyris has no radial vein of the fore wings, this applies only to $S$. unicus, since it is conspicuously present in S. montuosus. This broadens the concept of the genus. On the other hand, the characters related to the unusual wing venation of this genus are informative and will certain help to better understand the phylogeny of Sclerodermini.

The wing venation greatly differs among the genera of Sclerodermini, and helps determination of the genera (Azevedo 1992, 2006). However, some genera of this tribe (e.g. Sclerodermus Latreille and now Solepyris) have species with different wing venation patterns. The more visible difference between the two species of Solepyris, presence of radial vein in the fore wing, is one of the most important characters which differentiate Cephalonomia Westwood and Plastanoxus Kieffer. Characters related to wing venation are important not only to generic determination (Lanes \& Azevedo 2008), but also to species-level determinations within this tribe. The characters of wing venation could be very helpful to establish the cladistic relationships in this tribe. This scenario does not apply to others groups of Bethylidae.

Another evident difference between the two species of Solepyris is the conspicuousness of the scutellar groove. In S. unicus it is very shallow and barely visible, whereas it is wide, deep and obvious in S. montuosus, sp. nov. Differences related to the delimitation of scutellar groove and pits have been traditionally used to key the genera of Epyrini (e.g. Kieffer 1905; Evans 1964, 1978; Terayama 2003). However, such characters seem to be not useful to identify the genera or even to elucidate cladistic relationships among Epyrini (Waichert, pers. com.).

Acknowledgments. I am most grateful to all curators cited in the text for the loan of the material examined; to Isabel Alencar who scanned to the plates; to Felipe Fraga who edited the plates; to $\mathrm{CNPq}$ by the fellowship and financial support (grant \#303216/2004-2 and \#306331/2007-7) and Programa Taxonomia (grant \#563953/05-5).

\section{REFERENCES}

Azevedo, C. O. 1992. Sobre os Sclerodermini (Hymenoptera, Bethylidae, Epyrinae) da região de São Carlos, SP. Revista Brasileira de Entomologia 36: 561-567.

Azevedo, C. O. 1999. Revision of the Neotropical Dissomphalus Ashmead, 1893 (Hymenoptera, Bethylidae) with median tergal processes. Arquivos de Zoologia 35: 301-394.

Azevedo, C. O. 2006. Two new genera of Sclerodermini (Hymenoptera: Bethylidae: Epyrinae) with large, scolebythid-like prosternums. Zootaxa 1191: 35-47.

Evans, H. E. 1964. A synopsis of the American Bethylidae (Hymenoptera, Aculeata). Bulletin of the Museum of Comparative Zoology 132: 1-222.

Evans, H. E. 1978. The Bethylidae of America North of Mexico. Memoirs of the American Entomological Institute 27: 1332.

Harris, R. A. 1979. A glossary of surface sculpturing. Occasional Papers in Entomology 28: 1-31.

Kieffer, J. J. 1905. Description de nouveaux Proctotrypides exotiques. Analles de la Société Scientifique de Bruxelles, 2 Partie, 29: $121-122$.

Lanes, G. O. \& C. O. Azevedo. 2008. Phylogeny and taxonomy of Sclerodermini (Hymenoptera, Bethylidae, Epyrinae). Insect Systematics and Evolution 39: 55-86.

Terayama, M. 2003. Phylogeny Systematics of the family Bethylidae (Insecta: Hymenoptera) Part II. Keys to subfamilies, tribes and genera in the world. The Academic Reports the Faculty of Engineering Tokyo Polytechnic University 26: 16-29.

Received 12/07/2008; accepted 07/01/2009 